\title{
Digital radiography and ultrasonography in evaluation of the canine prostate
}

\author{
Radiografia digital e ultrassonografia na avaliação da próstata \\ canina
}

\author{
Bruna Naiara Moresco ${ }^{1 *}$; Gentil Ferreira Gonçalves ${ }^{2}$
}

\begin{abstract}
This study aimed to evaluate the canine prostate using ultrasonography and digital radiography. The study involved 21 intact dogs of mixed breed, with a mean weight of $8.7 \pm 3.09 \mathrm{~kg}$ and without previous hormonal treatment. The dogs were divided into three groups according to the age: GI ( $0-3$ years); GII (3-7 years); GIII (7+ years). Prostates from each animal were qualitatively and quantitatively evaluated by means of digital rectal examination, ultrasonography and digital radiography. A total of 882 measurements were obtained and 84 qualitative analyses. The results demonstrated association and high agreement between digital rectal examination and radiography for prostatomegaly diagnosis $(\mathrm{p}=$ $0.0030 ; \mathrm{K}=0.829268$ ). Ultrasonography and digital rectal examination did not present an association and had low agreement for diagnosis of alterations in prostatic parenchyma $(\mathrm{p}=1 ; \mathrm{K}=0.049383)$. Also, there was a difference between ultrasonographic and radiographic measurements (height: $\mathrm{p}=$ 0.0002; length: $\mathrm{p}<0.0001$; width: $\mathrm{p}<0.0001$ ). However, the measurements from distinct radiographic projections showed no difference between each other (width: $\mathrm{p}=0.3543$; length: $\mathrm{p}=0.3079$ and $\mathrm{p}$ $=0.9725$; height: $\mathrm{p}=0.3208$ ). Prostatic volume based on ultrasonographic measurements showed a positive correlation being proportional to the age of the $\operatorname{dog}(\mathrm{p}=0.0383)$. It was concluded that both methods, ultrasonography and radiography, are relevant diagnostic tools in evaluating the canine prostate, beyond just complementing each other. There are limitations associated with both imaging methods, which should be taken into consideration when planning a specific investigation of the canine prostate.
\end{abstract}

Key words: Canine Andrology. Dogs. Imaging diagnosis. Ultrasound. X-ray.

\section{Resumo}

\begin{abstract}
O presente estudo teve como objetivo avaliar a próstata canina utilizando equipamentos de ultrassonografia e radiografia digital. Foram avaliados 21 cães, sem raça definida, não submetidos à orquiectomia ou tratamento hormonal, com peso médio de $8.7 \pm 3.09 \mathrm{~kg}$, separados em três grupos por faixa etária: GI (0-3 anos); GII (3-7 anos); GIII (7+ anos). As próstatas dos cães foram avaliadas qualitativamente e quantitativamente por exame físico digital transretal, ultrassonografia e radiografia digital. Obteve-se o total de 882 mensurações e 84 análises qualitativas. Verificou-se associação e concordância ótima entre exame físico digital transretal e radiografia, para o diagnóstico de prostatomegalia $(\mathrm{p}=0.0030$; $\mathrm{K}=0.829268$ ). Ultrassonografia e exame físico digital transretal não apresentaram associação $\mathrm{e}$ concordância fraca, para diagnóstico de alterações no parênquima prostático $(\mathrm{p}=1 ; \mathrm{K}=0.049383)$.
\end{abstract}

1 Discente de Mestrado, Programa de Pós-Graduação em Saúde, Bem-estar e Produção Animal Sustentável na Fronteira Sul Universidade Federal da Fronteira Sul, Campus Realeza, UFFS, Realeza, PR, Brasil. E-mail: bruna-moresco@hotmail.com

2 Prof. Associado 1, Curso de Medicina Veterinária - Universidade Federal da Fronteira Sul, Campus Realeza, UFFS, Realeza, PR, Brasil. E-mail: gentil.goncalves@uffs.edu.br

* Author for correspondence 
Observou-se diferença entre as mensurações realizadas por ultrassonografia e radiografia (altura: $\mathrm{p}=$ 0.0002; comprimento: $\mathrm{p}<0.0001$; largura: $\mathrm{p}<0.0001)$. As mensurações a partir das diferentes projeções radiográficas não obtiveram diferença entre si (largura: $p=0.3543$; comprimento: $\mathrm{p}=0.3079$ e $\mathrm{p}=$ 0.9725; altura: $\mathrm{p}=0.3208)$. O volume prostático teve correlação positiva $(\mathrm{p}=0.0383)$ e foi diretamente proporcional à idade dos cães. Concluiu-se que ambas, ultrassonografia e a radiografia digital, são condutas diagnósticas relevantes na avaliação da próstata canina, além de complementares entre si. Contudo, há limitações associadas com cada método de imagem, as quais devem ser consideradas para a avaliação da próstata canina.

Palavras-chave: Cães. Diagnóstico por Imagem. Exame Andrológico. Ultrassom. Raios x.

\section{Introduction}

The canine prostate varies in size as a result of the influence of the natural aging process, breed, body weight, sexual maturity and disease (ATALAN et al., 1999a,b; DENNIS et al., 2010; GADELHA et al., 2008, 2009). The gland is present in all mammals but has clinical importance in humans and dogs due to the high incidence of diseases involving this organ (LEROY; NORTHRUP, 2009).

In general, prostatopathies cause alterations in prostatic volume and/or modify the appearance of the gland (GADELHA et al., 2008, 2009; LACRETA JUNIOR et al., 2012; LATTIMER; ESSMAN, 2014). The clinical signs are similar and unspecific, most of them associated with the compression that the affected gland exerts on adjacent anatomical structures, making it difficult to achieve a definitive clinical diagnosis (LATTIMER; ESSMAN, 2014; MUSSEL et al., 2010).

In this context, methods for investigating prostatic diseases have great importance in canine andrology, including digital rectal examination as one of the early techniques and an inexpensive method and imaging diagnosis with its broad range of techniques and continuous actualization.

Ultrasonography and radiography are imaging methods frequently cited by authors in studies of the canine prostate (ATALAN et al., 1999a,b; FREITAS et al., 2015; GADELHA et al., 2008; LACRETA JUNIOR et al., 2012; RUEL et al., 1998). However, studies that compare both methods are rare (ATALAN et al., 1999a). It is assumed that, identification of the positive and negative features of ultrasonography and radiography can help in the selection of a method according to the purpose of an investigation, since in veterinary practice it is uncommon to have access to all available diagnostic techniques (ATALAN et al., 1999c; KAMOLPATANA et al., 2000; RUEL et al., 1998).

In addition, research studies have been published which report formulae for determining canine prostatic volume based on ultrasonographic measurements (ATALAN et al., 1999c; KAMOLPATANA et al., 2000; RUEL et al., 1998). Thus, it is important to compare these formulae with the objective of evaluating their reproducibility. Beyond that, the accuracy of digital rectal examination in relation to imaging methods has been investigated in a few studies (GADELHA et al., 2009; MUKARATIRWA; CHITURA, 2007).

Therefore, the objective of this study was to measure and qualitatively evaluate the canine prostate using ultrasonography and digital radiography, comparing both imaging methods and relating the findings to the age of the dogs and results of digital rectal examination. In addition, this study involved analysis of the reproducibility of the available formulae for calculating prostatic volume.

\section{Materials and Methods}

\section{Ethics Committee}

This study was approved by the Ethics Committee of Animal Experimentation (CEUA/ UFFS), protocol no. 26596/2013. 
The study involved 21 male dogs with standardized weight and body score. The dogs were divided according to age into three groups, each containing seven animals. Group I (GI) was composed of dogs aged 0 to three years; group 2 (GII) contained dogs from three to seven years old; and group 3 (GIII) contained dogs aged seven years and older. The following characteristics applied to all dogs: medium size, mixed breed, entire, without previous hormonal treatment and clinically healthy. Twenty four hours prior to the examination, the dogs underwent preparation which involved treatment with laxative syrup lactulose $\left(667 \mathrm{mg} \mathrm{ml}^{-1}\right)$ as an oral dose of $1 \mathrm{ml}$ per $4.5 \mathrm{~kg}^{-1}$ bodyweight, three times a day, followed by 8 hours of fasting.

The digital rectal examination was carried out in the stationary animal. This was performed through the anus, using a gloved hand and the index finger lubricated with sterile aqueous gel (KY ${ }^{\circledR}$ gel). The radiographic images were obtained using mobile X-ray equipment (model Magvet ${ }^{\circledR} 320 \mathrm{~mA} 125 \mathrm{kv}$ ), processor and digital press (CARESTREAM $\AA$, models DirectView ${ }^{\circledR}$ CR XE and DryView ${ }^{\circledR} 5950$ ), with compatible software. The ultrasonographic images were obtained using an ultrasound machine (model Sonosite M-turbo ${ }^{\circledR}$ ) with micro convex transducer from 7-10 MHz.

Two independent evaluators performed the study. A total of 882 measurements and 84 qualitative analyses were obtained from the 21 dogs that were only physically restrained during examination.

Radiographic images were obtained of a standardized sequence of positions (ventrodorsal (VD), right lateral (RL), left lateral (LL) and dorsoventral (DV)), technique (100 mA, $10 \mathrm{mAs}$ and $60 \mathrm{kV}$ ), the collimator focused on the pelvic region and a radiographic cassette of a size appropriate for the dog.

Several measurements $(\mathrm{cm})$ were taken from the radiographic images of the prostate. Using VD and DV projections, width was measured from one lateral pole of the gland to the other $\left(\mathrm{W}^{\mathrm{rl}}\right.$ and
$\mathrm{W}^{\mathrm{r} 2}$ ), and length was measured from the cranial to the caudal pole of the gland $\left(\mathrm{L}^{\mathrm{r} 1}\right.$ and $\left.\mathrm{L}^{\mathrm{r} 2}\right)$. Using $\mathrm{RL}$ and $L L$ projections, length $\left(\mathrm{L}^{\mathrm{r} 3}\right.$ and $\left.\mathrm{L}^{\mathrm{r} 4}\right)$ and height $\left(\mathrm{H}^{\mathrm{r} 1}\right.$ and $\left.\mathrm{H}^{\mathrm{r}}\right)$ were determined; the latter value was derived from the distance between dorsal and ventral margins of the gland. In addition, using the RL projection, the relationship between craniocaudal prostatic length and pelvic inlet dimension was evaluated, as described by Dennis et al. (2010).

The ultrasonographic measurements $(\mathrm{cm})$ were conducted in triplicate, with the dog in a dorsal recumbent position. Using a longitudinal approach, length was measured from the cranial to the caudal pole of the gland $\left(\mathrm{L}^{\mathrm{u}}\right)$ and depth from the dorsal to the ventral margin $\left(\mathrm{D}^{\mathrm{ul}}\right)$. Based on a transverse view, width was measured from one lateral pole of the gland to the other $\left(\mathrm{W}^{\mathrm{u}}\right)$ and depth $\left(\mathrm{D}^{\mathrm{u} 2}\right)$. Prostatic volume $\left(\mathrm{cm}^{3}\right)$ was calculated from the ultrasonographic measurements using the following three formulae reported in the literature (ATALAN et al., 1999c; KAMOLPATANA et al., 2000; RUEL et al., 1998):

Formula 1 (ATALAN et al., 1999c):

$0.487 \times \mathrm{L} \times \mathrm{W} \times(\mathrm{DL}+\mathrm{DT}) / 2+6.38 \rightarrow \mathbf{( 0 . 4 8 7} \times$ $\left.\mathbf{L}^{\mathrm{u}} \times \mathrm{W}^{\mathrm{u}} \times\left(\mathrm{D}^{\mathrm{u} 1}+\mathrm{D}^{\mathrm{u} 2}\right) / 2\right)+\mathbf{6 . 3 8}$

Formula 2 (KAMOLPATANA et al., 2000):

$[1 / 2.6(\mathrm{~L} \times \mathrm{W} \times \mathrm{D})]+1.8 \rightarrow\left[\mathbf{1} / \mathbf{2 . 6}\left(\mathbf{L}^{\mathrm{u}} \times \mathbf{W}^{\mathrm{u}} \times\right.\right.$ $\left.\left.\left(\left(D^{\mathrm{u} 1}+\mathrm{D}^{\mathrm{u} 2}\right) / 2\right)\right)\right]+\mathbf{1 . 8}$

Formula 3 (RUEL et al., 1998):

$\left.\mathrm{L} \times \mathrm{D} \times \mathrm{W} \times 0.523 \rightarrow \mathbf{L}^{\mathrm{u}} \times\left(\left(\mathrm{D}^{\mathrm{u} 1}+\mathrm{D}^{\mathrm{u} 2}\right) / \mathbf{2}\right)\right) \times \mathbf{W}^{\mathrm{u}}$
$\times \mathbf{0 . 5 2 3}$

In addition to quantitative assessment, the prostates were qualitatively characterized using radiographic (LATTIMER; ESSMAN, 2014) and ultrasonographic images (FREITAS et al., 2015; GADELHA et al., 2009; TROISI et al., 2015).

Simple arithmetic mean values were determined from the triplicate measurements of ultrasonography and the measurements of the two evaluators. The data were analyzed for normality by the Kolmogorov- 
Smirnov test. Correlation between age and prostatic volume were investigated using Spearman's test. The paired t-test was applied for comparison between ultrasonographic and radiographic dimensions. Tukey's test was used to compare ultrasonographic measurements. Fischer's exact test and the kappa statistic were performed to determine association and agreement between imaging methods and digital rectal examination. Data tabulation and statistical analysis were performed using Microsoft Office Excel ${ }^{\circledR} 2016$ and Graphpad Prism ${ }^{\circledR} 5$ programs. Statistical significance was indicated by $\mathrm{p} \leq 0.05$.

\section{Results and Discussion}

The mean weights of the dogs $(\mathrm{kg})$ were 8.24 $\pm 2.44,8.84 \pm 2.99$ and $9.02 \pm 4.07$ in GI, GII and GIII, respectively. The mean age (years) in GI was $1.6 \pm 0.7$, in GII $4.7 \pm 1.7$ and in GIII $9.5 \pm 1.7$. The body score of all animals ranged between 4 and 6 , using a 1-9 scale (LAFLAMME, 1997).

Results of digital rectal examination of the prostate showed that the majority of the dogs (16/21) presented a normal gland; this was painless, had a smooth surface, soft consistency and regular size (GADELHA et al., 2009; MUKARATIRWA; CHITURA, 2007; PACLIKOVA et al., 2006; SMITH, 2008). In GII, one dog had abdominal location of the gland. In GIII, five dogs had that same location, and four had prostatic enlargement demonstrated by touch. Physiological growth of the canine prostate explains these findings; this is characterized by hypertrophy and hyperplasia of the prostatic cells and occurs under hormonal influence, mainly in entire dogs. Thus, during the aging process in dogs, the gland progressively becomes heavier, acquires abdominal location and increases in size (GADELHA et al., 2009; RUEL et al., 1998).

Through ultrasonography, it was possible to measure the prostate and examine its parenchyma, prostatic urethra, capsule, ducts, echogenicity, location and form, as described by Atalan et al. (1999c), Cooney et al. (1992), Gadelha et al. (2009) and Lacreta Junior et al. (2012). All dogs presented the same location of the gland, slightly caudal to the bladder, which is used as a marker. In general, younger dogs had a homogeneous prostatic parenchyma, whereas a heterogeneous gland was evident in dogs from GIII, indicated by periurethral ducts, multiples anechogenic and punctual hyperechogenic regions. These findings are also associated with the growing process of the prostate, in which the gland changes from a stromal structure to an organ organized into ducts and secretory components (COONEY et al., 1992; LEROY; NORTHRUP, 2009; LOWSETH et al., 1990).

It was possible to evaluate the prostatic urethra in all dogs from the transversal ultrasonographic view. This has a central location in the gland, characterized by a hypo or anechogenic region with a thin hyperechogenic layer, in accordance with Freitas et al. (2015).

The presence of prostatic cysts, as described by Dennis et al. (2010), was another common finding in this study. These occurred mainly in older dogs, contributing to the heterogeneous appearance of prostatic parenchyma in these animals, consistent with Cooney et al. (1992), Gadelha et al. (2009) and Ruel et al. (1998). Moreover, based on the description of benign prostatic hyperplasia (BPH) by Lacreta Junior et al. (2012), results of this study confirmed the presence of characteristics compatible with this disease in the majority of dogs from GIII.

Radiographic images showed that all dogs had a prostatic parenchyma compatible with soft tissue radiopacity, even in dogs that had evident parenchymal changes demonstrated by ultrasonography. It was noted that qualitative analysis is better performed through ultrasonography, which is a diagnostic tool used to differentiate possible abnormalities detected during radiographic examination (ATALAN, et al., 1999a; BRADBURY et al., 2009; DĘBIAK; BALICKI, 2009; FONSECA-ALVES et al., 2012; LATTIMER; ESSMAN, 2014; MUSSEL et al., 2010). 
Radiographic images showed that, in dogs where the prostate was in the pelvic location and/or with bone overlapping (GI and GII), the organ was more visible using VD projection. However, dogs in which the prostate was in the abdominal location and not superimposed could be better evaluated from RL or LL views, in accordance with Dębiak and Balicki (2009).

According to Lattimer and Essman (2014), the outline of the prostate is an important feature to be evaluated on radiographic images, given that it is directly related to radiographic contrast in the caudal abdomen or pelvic regions. These areas commonly have less contrast, mainly in younger dogs (DENNIS et al., 2010) or dogs with a low body score (LATTIMER; ESSMAN, 2014). In GI, no $\operatorname{dogs}$ showed sufficient radiographic contrast to demonstrate the prostatic outline. In four dogs from GII and four from GIII, the fat triangle was observed; this is a radiographic signal that can be formed due to prostatic enlargement or radiopacity difference between fat and soft tissue in the bladder and prostate region (DĘBIAK; BALICKI, 2009; DENNIS et al., 2010; LATTIMER; ESSMAN, 2014; PACLIKOVA et al., 2006; THRALL; ROBERTSON, 2011).

The relationship between craniocaudal prostatic length and the pelvic inlet dimension exceeded $70 \%$ in three dogs from GIII, characterizing prostatomegaly according to Dennis et al. (2010). These dogs also had the highest prostatic volumes and were diagnosed with prostatic enlargement by digital rectal examination.

Analysis of the association between digital rectal examination and radiographic diagnosis of prostatomegaly (DENNIS et al., 2010) demonstrated an association and high agreement between the methods ( $p=0.0030 ; K=0.829268)$. On the other hand, comparison between digital rectal examination and ultrasonographic findings showed no evidence of association and indicated low agreement ( $p=1$; $\mathrm{K}=0.049383$ ).

It was noted that prostatic alterations that were evident on ultrasonographic images were imperceptible using digital rectal examination, given that just an increase in prostatic size was diagnosed. According to Lattimer and Essman (2014), prostatic diseases generally cause enlargement of the gland. However, some diseases can alter the surface and consistency of the organ, such as paraprostatic cyst, abscess and neoplasia, while with other diseases changes are within the prostatic parenchyma and take a longer time to be detected by digital rectal examination, as BPH and internal cyst (JOHNSTON et al., 2000; SMITH, 2008).

Moreover, digital rectal examination only allows evaluation of the dorsal and dorsocaudal regions of the gland. Therefore, digital rectal examination can be used as a screening test in patients with clinical signs suggestive of prostatopathy or as a preventive examination in adult patients, because, despite its limitations, it provides an inexpensive procedure which is easy to perform (FONSECA-ALVES et al., 2012; GADELHA et al., 2009; MUKARATIRWA; CHITURA, 2007; SMITH, 2008).

There were differences between radiography and ultrasonography in terms of measurements of the prostate (height: $p=0.0002$; length: $p<0.0001$; width: $p<0.0001$; Table 1). In addition, radiographic dimensions were greater, partially corroborating findings of Atalan et al. (1999a). The magnification effect can explain the greater radiographic measurements in comparison with ultrasonography in this study (THRALL, 2014). On the other hand, as verified by Atalan et al. (1999c) and Gadelha et al. (2008), ultrasonography is a method that allows prostatic dimensions to be obtained which are very close to the actual size of the gland. 
Table 1. Comparison between ultrasonographic (US) and radiographic (RX) mean values of the canine prostate, in terms of height, length and width, with standard deviation. Mean values were obtained from 21 entire dogs of medium size $(8.7 \pm 3.09 \mathrm{~kg})$, mixed breed, without previous hormonal treatment and aged 0 to 7 years.

\begin{tabular}{ccccccc}
\hline & \multicolumn{2}{c}{ Height } & \multicolumn{2}{c}{ Length } & \multicolumn{2}{c}{ Width } \\
\cline { 2 - 7 } & US & RX & US & RX & US & RX \\
$\mathrm{cm}$ & $1.96 \pm 0.42^{\mathrm{a}}$ & $2.32 \pm 0.52^{\mathrm{b}}$ & $2.45 \pm 0.65^{\mathrm{a}}$ & $2.97 \pm 0.55^{\mathrm{b}}$ & $2.85 \pm 0.74^{\mathrm{a}}$ & $3.46 \pm 0.48^{\mathrm{b}}$ \\
\hline $\mathrm{p}$ & \multicolumn{3}{c}{$=0.0002$} & $<0.0001$ & & \multicolumn{2}{c}{$<0.0001$} \\
\hline
\end{tabular}

a; $:$ : values with different letters represent statistically significant difference using the paired t-test, $p<0.05$.

There was no difference between the four radiographic projections in terms of width, length or height $(\mathrm{p}=0.3543 ; \mathrm{p}=0.3079 ; \mathrm{p}=0.9725$; $\mathrm{p}=0.3208$; Table 2). This result demonstrates that, when measuring the canine prostate using radiographic examination, similar measurements are obtained when the animal is in any of the four standard positions. However, many aspects limit the precision of prostate measurements using radiographic images, as superimposition of structures, radiographic contrast and magnification effects (DĘBIAK; BALICKI, 2009; DENNIS et al., 2010; LATTIMER; ESSMAN, 2014; PACLIKOVA et al., 2006; THRALL, 2014; THRALL; ROBERTSON, 2011).

Table 2. Comparison between radiographic mean $(\mathrm{cm})$ of the canine prostate obtained from four radiographic projections, by analyzing height, length and width, with standard deviation. Mean values were obtained from 21 entire dogs of medium size $(8.7 \pm 3.09 \mathrm{~kg})$, mixed breed, without previous hormonal treatment and aged 0 to 7 years.

\begin{tabular}{ccccccccc}
\hline & \multicolumn{2}{c}{ Width } & \multicolumn{2}{c}{ Length } & \multicolumn{2}{c}{ Length } & \multicolumn{2}{c}{ Height } \\
\cline { 2 - 9 } $\mathrm{cm}$ & $\mathrm{VD}^{\mathrm{a}}$ & $\mathrm{VD}^{\mathrm{b}}$ & $\mathrm{DV}^{\mathrm{b}}$ & $\mathrm{RL}^{\mathrm{c}}$ & $\mathrm{LL}^{\mathrm{c}}$ & $\mathrm{RL}^{\mathrm{d}}$ & $\mathrm{LL}^{\mathrm{d}}$ \\
\cline { 2 - 8 } & $3.44 \pm 0.48$ & $3.49 \pm 0.51$ & $3.06 \pm 0.64$ & $2.99 \pm 0.49$ & $2.93 \pm 0.62$ & $2.93 \pm 0.64$ & $2.34 \pm 0.54$ & $2.30 \pm 0.50$ \\
\cline { 2 - 7 }
\end{tabular}

\begin{tabular}{|c|c|c|c|c|}
\hline $\mathrm{p}$ & $=0.3543$ & $=0.3079$ & $=0.9725$ & $=0.3208$ \\
\hline
\end{tabular}

a; b; c; d: equal letters in the same line indicate no statistically significant difference using the paired t-test, $\mathrm{p}<0.05$

VD: ventrodorsal; DV: dorsoventral; RL: right lateral; LL: left lateral.

With regard to ultrasonographic mean values obtained in this study (Table 3), these were smaller than those reported by Atalan et al. (1999a) for dogs with prostatopathy, whereas the values were similar to measurements from histologically normal prostates (ATALAN et al., 1999b).

However, analysis of ultrasonographic dimensions according to age group (Table 3 ) showed that dogs in GIII had measurements compatible with those with hyperplastic glands described by Atalan et al. (1999c), and above the values in healthy dogs determined by Atalan et al. (1999b). GI and GII presented mean values compatible with dogs with normal prostates, according to the same authors. It is noted that prostate length determined by ultrasonography showed a difference between the three groups $(\mathrm{p}=0.0062$; Table 3$)$. In fact, there is little resistance to longitudinal growth of the prostate compared to growth in the dorsoventral direction, which is limited by the presence of the colon and pelvic bones (ATALAN et al., 1999a). 
Table 3. Ultrasonographic mean values $(\mathrm{cm})$ for height, length and width, and prostatic volume $\left(\mathrm{cm}^{3}\right)$, according to the age of dogs (GI: 0-3 years; GII: 3-7 years; GIII: +7 years), with standard deviation. Measurements were obtained from 21 entire dogs of medium size $(8.7 \pm 3.09 \mathrm{~kg})$, mixed breed, without previous hormonal treatment and aged 0 to 7 years.

\begin{tabular}{|c|c|c|c|c|c|c|}
\hline & Height & Length & Width & & Volume & \\
\hline & & & & F1 & F2 & F3 \\
\hline GI & $1.83 \pm 0.36$ & $2.04 \pm 0.30$ & $2.40 \pm 0.46$ & $11.06 \pm 2.25^{\mathrm{a}}$ & $5.49 \pm 1.77^{\mathrm{a}}$ & $5.03 \pm 2.42^{\mathrm{a}}$ \\
\hline GII & $1.94 \pm 0.11$ & $2.28 \pm 0.27$ & $2.82 \pm 0.43$ & $12.61 \pm 2^{b}$ & $6.72 \pm 1.58^{\mathrm{b}}$ & $6.71 \pm 2.16^{\mathrm{b}}$ \\
\hline GIII & $2.11 \pm 0.63$ & $3.02 \pm 0.80$ & $3.33 \pm 0.97$ & $18.67 \pm 9.59^{c}$ & $11.51 \pm 7.57^{\circ}$ & $13.22 \pm 10.31^{\mathrm{c}}$ \\
\hline $\mathrm{p}$ & $=0.4791$ & $=0.0062^{\mathrm{d}}$ & $=0.0574$ & $=0.0383$ & $=0.0383$ & $=0.0383$ \\
\hline $\begin{array}{l}\text { d: } \text { GI: } 0-3 \text { y } \\
\text { F1: Form } \\
\text { F2: Form } \\
\text { F3: Form }\end{array}$ & $\begin{array}{l}\text { ith equal lette } \\
\text { group using S } \\
\text { ignificant diffe } \\
\text { GII: } 3-7 \text { years } \\
\text { (ATALAN et } \\
\text { (KAMOLPAT } \\
\text { (RUEL et al., }\end{array}$ & $\begin{array}{l}\text { the same lin } \\
\text { nan's test, } p<0 \\
\text { e between grou } \\
\text { I: } 7+\text { years } \\
999 \text { c) } \\
\text { et al., 2000) } \\
\text { ). }\end{array}$ & $\begin{array}{l}\text { resent positiv } \\
\text { sing Tukey's }\end{array}$ & $\begin{array}{l}\text { elation bety } \\
<0.05\end{array}$ & vo & nean ag \\
\hline
\end{tabular}

Gadelha et al. $(2008,2009)$ reported the largest prostate dimensions in older dogs, in agreement with the present study. Moreover, this study showed a gradual increase in prostatic volume with advancing age of the dog $(\mathrm{p}=0.0383$; Table 3). According to Lattimer and Essman (2014) and Leroy and Northrup (2009), cystic hyperplasia, which is an advanced $\mathrm{BPH}$, affects dogs older than six years of age. This disease is characterized, not just by a diffuse proliferation of secretory epithelium, but also by an increase in the stromal component of the gland, resulting in an increased volume.

Mean values for prostatic volume in GIII were bigger than those reported for healthy dogs by Atalan et al. (1999b). In contrast, smaller dimensions were reported for GI, GII and GIII compared with the findings of Nair et al. (2012). Both cited studies used formula 1 for calculations. Using formula 2, this study obtained dimensions significantly different to those of Korodi et al. (2010), while formula 3 generated smaller values compared with those of Freitas et al. (2015), Moxon et al. (2015) and Ruel et al. (1998) (Table 3). It is noteworthy that all the comparative studies showed differences in the characteristics of the selected dogs, mainly with regard to breed, weight and age.

Ghadiri et al. (2013) tested the elliptic formula, proposed by Ruel et al. (1998), and the quadratic formula used by Atalan et al. (1999c) and Kamolpatana et al. (2000). The authors reported mean prostatic volumes of $16.68 \mathrm{~cm}^{3}$ (elliptic) and $31.85 \mathrm{~cm}^{3}$ (quadratic) based on ultrasonographic measurements, whereas the actual dimensions of the same glands were $8.68 \mathrm{~cm}^{3}$ (elliptic) and 16.75 $\mathrm{cm}^{3}$ (quadratic). As explained by the authors, the formulae do not calculate the prostatic volume accurately. However, it is evident that there is a tendency for prostatic volume to increase with the age of the dog, which was observed in this present study using all formulae and corroborates the findings of Atalan et al. (1999b), Freitas et al. (2015), Korodi et al. (2010), Lowseth et al. (1990), Nair et al. (2012) and Ruel et al. (1998).

In this present study, it was impossible to choose a standard formula to measure canine prostatic volume. As mentioned by Atalan et al. (1999c), sonographic transducer rotation can substantially change ultrasonographic measurements, causing them to become smaller or larger and these dimensions are then used in the formulae to calculate 
prostatic volume. This inter- and intra-variability between measurements can cause calculations using the different formulae to be inaccurate and unreproducible.

\section{Conclusions}

Ultrasonography was superior in comparison with radiography in terms of the evaluation of prostatic parenchyma. In contrast, radiography was more effective in evaluating the prostate with regard to its location and relationship with adjacent organs. In relation to prostate size, the selected imaging method is significantly relevant to this evaluation. There are limitations associated with both imaging methods, which should be taken into consideration when planning a specific investigation of the canine prostate. In addition, this study confirms gradual changes in location, size and parenchyma of the canine prostate with aging process. Finally, the three tested formula showed inaccurate and unreproducible, using ultrasonographic measurements.

\section{References}

ATALAN, G.; BARR, F. J.; HOLT, P. E. Comparison of ultrasonographic and radiographic measurements of canine prostate dimensions. Veterinary Radiology \& Ultrasound, Clemson, v. 40, n. 4, p. 408-412, 1999a.

ATALAN, G.; HOLT, P. E.; BARR, F. J. Ultrasonographic estimation of prostate size in normal dogs and relationship to bodyweight and age. Journal of Small Animal Practice, Malden, v. 40, n. 3, p. 119-122, 1999b.

ATALAN, G.; HOLT, P. E.; BARR, F. J.; BROWN, P. J. Ultrasonographic estimation of prostatic size in canine cadavers. Research in Veterinary Science, Penicuik, v. 67 , n. 1, p. 7-15, 1999c.

BRADBURY, C. A.; WESTROPP, J. L.; POLLARD, R. E. Relationship between prostatomegaly, prostatic mineralization, and cytologic diagnosis. Veterinary Radiology \& Ultrasound, Clemson, v. 50, n. 2, p. 167171, 2009.

COONEY, J. C.; CARTEE, R. E.; GRAY, B. W.; RUMPH, P. F. Ultrasonography of the canine prostate with histologic correlation. Theriogenology, New York, v. 38 , n. 5 , p. $877-895,1992$.

DĘBIAK, P.; BALICKI, I. Diagnostic imaging of the canine prostate gland subject to its location and size. Bulletin of the Veterinary Institute in Pulawy, Berlin, v. 53, n. 2, p. 313-317, 2009.

DENNIS, R.; KIRBERGER, R. M.; BARR, F.; WRIGLEY, R. H. Urogenital tract. In: DENNIS, R.; KIRBERGER, R. M.; BARR, F.; WRIGLEY, R. H. Handbook of small animal radiology and ultrasound: techniques and differential diagnoses. $2^{\text {th }}$ ed. Edinburgh: Saunders Elsevier, 2010. p. 297-330.

FONSECA-ALVES, C. E.; CORRÊA, A. G.; SANTOSJUNIOR, H. L.; ELIAS, F.; COSTA, S. S.; MOURA, V. M. B. D. Abcesso prostático em cães: relato de 15 casos. Semina: Ciências Agrárias, Londrina, v. 33, n. 3, p. 1157-1164, 2012.

FREITAS, L.A.; PINTO, J. N.; SILVA, H. V. R.; SILVA, L. D. M. Two-dimensional and Doppler sonographic prostatic appearance of sexually intact French Bulldogs. Theriogenology, New York, v. 83, n. 7, p. 1140-1146, 2015.

GADELHA, C. R. F.; VICENTE, W. R. R.; RIBEIRO, A. P. C.; APPARÍCIO, M. F.; COVIZZI, G. J.; MACHADO, L. D. S. Age-related ultrasonography, cytology, and microbiologic exam of canine prostate. Arquivo Brasileiro de Medicina Veterinária e Zootecnia, Belo Horizonte, v. 61, n. 6, p. 1261-1267, 2009.

GADELHA, C. R. F.; VICENTE, W. R. R.; SILVA, L. D. M.; ALENCAR, A. A.; CAMPOS, A. C. N.; LIMA, T. S.; DIÓGENES, D. Mensuração ultra-sonográfica e física da próstata canina. Ciência Animal, Fortaleza, v. 18, n. 2, p. 51-56, 2008.

GHADIRI, A.; AVIZEH, R.; BANIADAM, A.; RANJBAR, A. Comparison of transabdominal and transrectal ultrasonography of the prostate gland in dogs. Iranian Journal of Veterinary Surgery, Kerman, v. 8, n. 2, p. 43-48, 2013.

JOHNSTON, S. D.; KAMOLPATANA, K.; ROOTKUSTRITZ, M. V.; JOHNSTON, G. R. Prostatic disorders in the dog. Animal Reproduction Science, Belfield, v. 60-61, p. 405-415, 2000.

KAMOLPATANA, K.; JOHNSTON, G. R.; JOHNSTON, S. D. Determination of canine prostatic volume using trans abdominal ultrasonography. Veterinary Radiology \& Ultrasound, Clemson, v. 41, n. 1, p. 73-77, 2000.

KORODI, G.; COLIBAR, O.; CERNESCU, H.; ARDELEAN, V.; BONCA, G.; MIRCU, C.; POPOVICI, D. Study regarding the evolution with age of ultrasound 
prostate dimensions in German Shepherd dogs. Journal of Animal Science and Biotechnologies, Beijing, v. 43, n. 1, p. 182-184, 2010.

LACRETA JUNIOR, A. C. C.; CASTRO, M. B.; SOBREIRA, L. F. R.; CANOLA, J. C. Aspectos ultrassonográficos e citopatológicos das prostatopatias em 52 cães. Revista Biotemas, Florianópolis, v. 25, n. 1, p. 137-149, 2012.

LAFLAMME, D. P. Development and validation of a body condition score system for dogs. Canine Practice, Santa Bárbara, v. 22, n. 4, p. 10-15, 1997.

LATTIMER, J. C.; ESSMAN, S. C. Próstata. In: THRALL, D. E. Diagnóstico de radiologia veterinária. 6. ed. Rio de Janeiro: Elsevier, 2014. p. 749-756.

LEROY, B. E.; NORTHRUP, N. Prostate cancer in dogs: comparative and clinical aspects. The Veterinary Journal, Indiana, v. 180, n. 2, p. 149-162, 2009.

LOWSETH, L. A.; GERLACH, R. F.; GILLETT, N. A.; MUGGENBURG, B. A. Age-related changes in the prostate and testes of the beagle dog. Veterinary Pathology, Ontario, v. 27, n. 5, p. 347-353, 1990.

MOXON, R.; BRIGHT, L.; PRITCHARD, B.; BOWEN, I. M.; SOUZA, M. B.; SILVA, L. D. M.; ENGLAND, G. C. W. Digital image analysis of testicular and prostatic ultrasonographic echogencity and heterogeneity in dogs and the relation to semen quality. Animal Reproduction Science, Belfield, v. 160, p. 112-119, 2015.

MUKARATIRWA, S.; CHITURA T. Canine subclinical prostatic disease: histological prevalence and validity of digital rectal examination as a screening test. Journal of the South African Veterinary Association, Pretoria, v. 78, n. 2, p. 66-68, 2007.
MUSSEL, C.; MELO, F. R.; BLUME, H.; MULINARI, F. Métodos de diagnóstico para detecção de prostatopatias caninas. Ciência Rural, Santa Maria, v. 40, n. 12, p. 2616-2622, 2010.

NAIR, D. R.; GHOSH, K. N. A.; HARSHAN, H. M. Estimation of prostatic size in dogs using transabdominal ultrasonography. Indian Journal of Animal Reproduction, Chennai, v. 33, n. 2, p. 79-81, 2012.

PACLIKOVA, K.; KOHOUT, P.; VLASIN, M. Diagnostic possibilities in the management of canine prostatic disorders. Veterinarni Medicina, Brno, v. 51, n. 1, p. 1-13, 2006.

RUEL, Y.; BARTHEZ, P. Y.; MAILLES, A.; BEGON, D. Ultrasonographic evaluation of the prostate in healthy intact dogs. Veterinary Radiology \& Ultrasound, Clemson, v. 39, n. 3, p. 212-216, 1998.

SMITH, J. Canine prostatic disease: A review of anatomy, pathology, diagnosis, and treatment. Theriogenology, New York, v. 70, n. 3, p. 375-383, 2008.

THRALL, D. E. Introdução à interpretação radiográfica. In: THRALL, D. E. Diagnóstico de radiologia veterinária. 6. ed. Rio de Janeiro: Elsevier, 2014. p. 7486.

THRALL, D. E.; ROBERTSON, I. D. The abdomen. In: THRALL, D. E.; ROBERTSON, I. D. Atlas of normal radiographic anatomy and anatomic variants in the dog and cat. $2^{\text {th }}$ ed. St. Louis: Elsevier, 2011. p. 253-295.

TROISI, A.; ORLANDI, R.; BARGELLINI, P.; MENCHETTI, L.; BORGES, P.; ZELLI, R.; POLISCA, A. Contrast-enhanced ultrasonographic characteristics of the diseased canine prostate gland. Theriogenology, New York, v. 84, n. 8, p. 1423-1430, 2015. 
